\title{
Metabolic efficiency and energy expenditure during short-term overfeeding
}

Citation for published version (APA):

Joosen, A. M. C. P., Bakker, A. H. F., \& Westerterp, K. R. (2005). Metabolic efficiency and energy expenditure during short-term overfeeding. Physiology \& Behavior, 85(5), 593-597. https://doi.org/10.1016/j.physbeh.2005.06.006

Document status and date:

Published: 01/01/2005

DOI:

10.1016/j.physbeh.2005.06.006

Document Version:

Publisher's PDF, also known as Version of record

Document license:

Taverne

Please check the document version of this publication:

- A submitted manuscript is the version of the article upon submission and before peer-review. There can be important differences between the submitted version and the official published version of record.

People interested in the research are advised to contact the author for the final version of the publication, or visit the DOI to the publisher's website.

- The final author version and the galley proof are versions of the publication after peer review.

- The final published version features the final layout of the paper including the volume, issue and page numbers.

Link to publication

\footnotetext{
General rights rights.

- You may freely distribute the URL identifying the publication in the public portal. please follow below link for the End User Agreement:

www.umlib.nl/taverne-license

Take down policy

If you believe that this document breaches copyright please contact us at:

repository@maastrichtuniversity.nl

providing details and we will investigate your claim.
}

Copyright and moral rights for the publications made accessible in the public portal are retained by the authors and/or other copyright owners and it is a condition of accessing publications that users recognise and abide by the legal requirements associated with these

- Users may download and print one copy of any publication from the public portal for the purpose of private study or research.

- You may not further distribute the material or use it for any profit-making activity or commercial gain

If the publication is distributed under the terms of Article $25 \mathrm{fa}$ of the Dutch Copyright Act, indicated by the "Taverne" license above, 


\title{
Metabolic efficiency and energy expenditure during short-term overfeeding
}

\author{
Annemiek M.C.P. Joosen *, Arjen H.F. Bakker, Klaas R. Westerterp \\ Department of Human Biology, Maastricht University, P.O. Box 6166200 MD Maastricht, The Netherlands
}

Received 9 November 2004; received in revised form 27 January 2005; accepted 20 June 2005

\begin{abstract}
Objective: To investigate whether efficiency of weight gain during a short period of overfeeding is related to adaptive differences in basal metabolic rate (BMR) and physical activity.

Subjects: Fourteen healthy females (age $25 \pm 4$ years, BMI $22.1 \pm 2.3 \mathrm{~kg} / \mathrm{m}^{2}$ ).

Design and measurements: Subjects were overfed with a diet supplying 50\% more energy than baseline energy requirements for 14 days. Overfeeding diets provided $7 \%$ of energy from protein, $40 \%$ from fat and 53\% from carbohydrates. Body composition was determined using hydrodensitometry and isotope dilution, total energy expenditure (TEE) with doubly labeled water and basal metabolic rate (BMR) with indirect calorimetry. Physical activity (PA) was recorded with a tri-axial accelerometer.

Results: Body weight increased by $1.45 \pm 0.86 \mathrm{~kg}$ (mean \pm S.D.) $(P<0.0001)$, fat mass increased by $1.05 \pm 0.75 \mathrm{~kg}$. Energy storage was $57.0 \pm 17.9 \mathrm{MJ}$, which is the difference between energy intake (207.2 MJ) and energy expenditure (150.2 MJ) during overfeeding. There was no difference between metabolically efficient and metabolically inefficient subjects in changes in BMR and PA.

Conclusion: These results indicate that the metabolic efficiency of weight gain was not related to adaptive changes in energy expenditure. (C) 2005 Published by Elsevier Inc.
\end{abstract}

Keywords: Energy expenditure; Physical activity; Doubly labeled water; Accelerometer; Overfeeding

\section{Introduction}

An energy intake that exceeds energy expenditure for longer periods will lead to weight gain. However, when healthy adults are overfed, most persons gain less weight than expected from the excess energy intake and show a wide inter-individual range in weight gain on the same overfeeding regime [1-6]. One possible explanation is that some persons can increase their energy expenditure when overeating to resist weight gain. Whether there are adaptive physiological changes in energy expenditure is studied intensively. While some investigators found evidence for adaptive thermogenesis [7] others did not [1,8,9] but accuracy and sophistication of methods used to measure

\footnotetext{
* Corresponding author. Tel.: +31 43 3882115; fax: +31 433670976 .

E-mail address: A.Joosen@HB.Unimaas.NL (A.M.C.P. Joosen).
}

energy expenditure and physical activity could be improved. Three overfeeding studies, approximately comparable in amount and duration of overfeeding, measured free-living energy expenditure with doubly labeled water but reached different conclusions. Levine et al. [5] found that individual changes in non-exercise activity thermogenesis (NEAT), defined as the thermogenesis associated with fidgeting, maintenance of posture and other activities of daily life, could explain differences in fat gain in subjects overfed with 4.2 MJ/day for 56 days. Diaz et al. [3] found no evidence for any adaptive energy-dissipating mechanism when overfeeding subjects with $50 \%$ more energy than baseline requirements (mean 6.2 MJ/day) for 42 days. Also, Roberts et al. [4] did not find a significant increase in energy expenditure in young and older men overfed with $4.2 \mathrm{MJ} /$ day for 21 days.

Diet composition is known to influence energy expenditure, as different substrates will increase dietary induced 
thermogenesis (DIT) to various degrees. DIT is greater on a high protein and carbohydrate diet than on a fat diet [10]. In several studies the metabolic response to overfeeding diets of different composition (low-protein, high-carbohydrate, high-fat) has been investigated $[6,7,11,12]$. These experiments show considerable inter-individual differences in energy cost of weight gain within and between experiments. Stock [13] and Dulloo and Jacquet [14] showed that differences were most noticeable when diets were unbalanced with respect to protein and therefore suggested that overfeeding low-protein diets could serve as a tool to exaggerate individual differences in energetic efficiency by maximizing DIT. We overfed 14 healthy females with a low-protein diet to investigate whether efficiency of weight gain is related to adaptive differences in BMR and physical activity.

\section{Subjects and methods}

\subsection{Subjects}

Fourteen healthy female subjects, aged 19-36 years, participated in the study. Characteristics of the subjects are shown in Table 1. Before participating in the study subjects were medically screened by a detailed health questionnaire. Subjects had had a stable body weight (body weight changes $\leq 2 \mathrm{~kg}$ ) for at least a year at the start of the study. Three were light smokers, they maintained their habitual smoking pattern during the study. All subjects received verbal and written information and signed a written consent form. The study was approved by the Ethics Committee of Maastricht University.

\subsection{Experimental design}

Baseline energy requirements were defined over a 7-day period (days 1-8). During the 14-day overfeeding period (days $8-22$ ) subjects were overfed with a diet supplying $50 \%$ more energy than the baseline energy requirements. All foods and drinks were provided daily in weighed food packages while subjects consumed the main course (dinner) at the university. Alcohol consumption was not allowed during the study. Body weight was measured on days 1,8 and 22. Body composition and basal metabolic rate were measured at baseline and after overfeeding (days 8 and 22). Total energy expenditure was measured with doubly

Table 1

Initial characteristics of the 14 female subjects

\begin{tabular}{lcl}
\hline & Mean & SD \\
\hline Age (years) & 25 & 4 \\
Height $(\mathrm{m})$ & 1.72 & 0.06 \\
Body weight $(\mathrm{kg})$ & 64.8 & 7.0 \\
Body mass index $\left(\mathrm{kg} / \mathrm{m}^{2}\right)$ & 22.1 & 2.3 \\
Body fat $(\%)$ & 27.5 & 4.4 \\
\hline
\end{tabular}

labeled water during the 2 weeks preceding overfeeding ( $n=7$, because of limited availability of doubly labeled water) and during the 2 weeks of overfeeding $(n=14)$. For the entire study period subjects wore an accelerometer to measure physical activity. Subjects maintained their normal lifestyles (i.e. work, education, sports participation) throughout the study.

\subsection{Dietary intake}

During the baseline period subjects chose their diets from a variety of food items provided daily in weighed food packages, bringing back the left-overs the next day, for calculation of habitual energy intake. When subjects had not been in energy balance (i.e. body weight changed from day 1 to day 8), baseline energy requirements were calculated from basal metabolic rate measured with indirect calorimetry and physical activity level measured with accelerometry. Subjects were overfed with a diet containing $50 \%$ more energy than the baseline energy requirements. The excess energy intake during the overfeeding period was introduced gradually to allow the bowels to adjust to the increased amount of food. Overfeeding diets were calculated to be relatively low in protein, providing 7\% of energy from protein as derived from the analysis of overfeeding experiments by Stock [13], 40\% from fat and 53\% from carbohydrates. Food composition of the diets was largely the same for each subject, but some adjustments were made according to the subject's preferences to make the overfeeding diets more palatable. All foods and drinks were weighed to the nearest gram. Macronutrient composition of baseline and overfeeding diets was assessed with a computerized version of the Dutch food composition table (Komeet, version 2.0d, 1996, B·ware Nutrition Software).

\subsection{Procedures}

Anthropometry and body composition. Measurements were carried out in the morning after voiding and before breakfast. Body weight and height were measured to the nearest $0.01 \mathrm{~kg}$ and $0.1 \mathrm{~cm}$, respectively. Body mass index (BMI, $\left.\mathrm{kg} / \mathrm{m}^{2}\right)$ was calculated as body weight $(\mathrm{kg})$ divided by height $(\mathrm{m})$ squared. Body composition was estimated by using hydrodensitometry and isotope dilution. Body density was determined by underwater weighing with simultaneous measurement of residual lung volume with the helium dilution technique. Total body water (TBW) was determined with deuterium dilution following the Maastricht protocol [15]. Body composition was calculated from body density and TBW using the three-compartment model of Siri [16].

Total energy expenditure. Total energy expenditure (TEE) was measured with the doubly labeled water (DLW) technique following the Maastricht protocol [15]. Briefly, isotopes were administered as a mixture of 5 at $\%$ ${ }^{2} \mathrm{H}_{2} \mathrm{O}$ and 10 at $\% \mathrm{H}_{2}^{18} \mathrm{O}$ resulting in an initial excess body 
water enrichment of $150 \mathrm{ppm}$ for deuterium and $300 \mathrm{ppm}$ for oxygen-18, leaving a sufficient excess enrichment at the end of the observation period. The volume was $80-160 \mathrm{ml}$. Subjects collected a background urine sample immediately before isotope consumption to correct for isotopic backgrounds, subsequent urine samples were collected from the second and the last voiding on the first, mid and last day of the 14-day observation period. Isotope enrichments of the urine samples were analyzed with isotope ratio mass spectrometry (Optima, VG, UK). Theoretical considerations and calculations of energy expenditure by the DLW method as described in detail elsewhere by Westerterp et al. [15] were checked for validity during overfeeding.

Basal metabolic rate. Basal metabolic rate (BMR) was measured by indirect calorimetry using an open-circuit, ventilated-hood system [17] in the morning after an overnight fast with subjects lying in a supine position for $30 \mathrm{~min}$. BMR was calculated from $\mathrm{O}_{2}$ consumption and $\mathrm{CO}_{2}$ production using the formula of Weir [18].

Physical activity. Physical activity was registered with a tri-axial accelerometer for movement registration (Tracmor, Philips Research, Eindhoven, The Netherlands), which measures frequencies covering the frequency content of activities of daily living [19]. The tri-axial accelerometer has been validated against DLW [20] and has been used before in our department $[21,22]$. Subjects wore the accelerometer on a belt at the lower back during waking hours.

\subsection{Statistical analysis}

All results are presented as mean \pm S.D. Student's paired $t$-test (two-sided) was used to compare parameters before and after overfeeding. A simple regression analysis between weight gain and energy storage (which is the difference between energy intake and energy expenditure during overfeeding) was used to distinguish between metabolically efficient (positive residuals) and metabolically inefficient (negative residuals) subjects. Metabolically efficient and inefficient subjects were compared regarding changes in BMR and physical activity using a one-way ANOVA. $P<0.05$ was considered as statistically significant. SPSS 11 for Macintosh (2002, SPSS Inc.) was used for the analysis.

\section{Results}

\subsection{Dietary intake}

Table 2 summarizes the changes in energy balance parameters induced by overfeeding. Self-selected baseline diets provided mean percentages energy of $14 \pm 2 \%$ from protein, $30 \pm 3 \%$ from fat and $57 \pm 4 \%$ from carbohydrates. The macronutrient composition of the overfeeding diets was as intended: $7 \%$ of energy from protein, $40 \%$ from fat and $53 \%$ from carbohydrates, which was low in protein on a
Table 2

Energy balance parameters at baseline and after 14 days overfeeding*

\begin{tabular}{lccc}
\hline & Baseline & Overfeeding & $P^{\dagger}$ \\
\hline Body weight $(\mathrm{kg})$ & $64.8 \pm 7.0$ & $66.3 \pm 6.7$ & $<0.0001$ \\
Fat mass $(\mathrm{kg})$ & $18.0 \pm 4.5$ & $19.0 \pm 4.3$ & $<0.001$ \\
Energy intake (MJ/day) & $9.2 \pm 1.2$ & $14.8 \pm 1.6$ & $<0.0001$ \\
TEE (MJ/day) $(n=7)$ & $10.18 \pm 0.68$ & $10.58 \pm 1.00$ & 0.10 \\
\multicolumn{1}{c}{$(n=14)$} & - & $10.73 \pm 1.06$ & - \\
BMR (MJ/day) & $5.74 \pm 0.37$ & $6.13 \pm 0.56$ & $<0.01$ \\
Physical activity (Mcounts/day) & $6666 \pm 1286$ & $7177 \pm 1645$ & 0.21 \\
Energy storage (=EI - TEE) (MJ) & - & $57.0 \pm 17.9$ & - \\
\hline
\end{tabular}

*mean \pm S.D., ${ }^{\dagger}$ Student's paired $t$-test (two-sided), TEE $=$ total energy expenditure, $\mathrm{BMR}=$ basal metabolic rate, $\mathrm{EI}=$ energy intake.

relative basis (\%) and on an absolute basis $(61 \pm 6.1 \mathrm{~g} /$ day $)$. The mean energy intake during baseline was $9.2 \pm 1.2 \mathrm{MJ} /$ day. During overfeeding mean energy intake was $14.8 \pm 1.6$ $\mathrm{MJ} /$ day or a total of $207.2 \pm 21.6 \mathrm{MJ}$ (Table 2).

\subsection{Body weight and body composition}

Body weight increased by $1.45 \pm 0.86 \mathrm{~kg}(P<0.0001)$ with a range from 0.19 to $3.00 \mathrm{~kg}$. Fat mass increased by $1.05 \pm 0.75 \mathrm{~kg}(P<0.001)$ ranging from 0.12 to $2.65 \mathrm{~kg}$ (Table 2). There was no significant effect of menstrual cycle (defined as the change from pre- to post-ovulation $(n=6)$ or from post-to pre-ovulation $(n=8)$ during the overfeeding period) on weight gain, neither alone nor after correction for energy storage (data not shown).

\subsection{Metabolic efficiency and energy expenditure}

There were no indications for malabsorption, therefore energy storage was calculated as the difference between energy intake (207.2 MJ) and energy expenditure (150.2 MJ) during overfeeding. Mean energy storage was 57.0 \pm 17.9 MJ (Table 2).

Fig. 1 shows the individual changes in body weight plotted against energy storage. Subjects with a positive residual from the regression line were considered metabolically efficient (relatively high weight gain for the amount of energy stored), subjects with a negative residual from the regression line were considered metabolically inefficient (relatively low weight gain for the amount of energy stored). For the whole group mean BMR increased significantly with $0.38 \pm 0.47 \mathrm{MJ} /$ day $(P<0.01)$, with a large interindividual variation. When comparing metabolically efficient and inefficient subjects we did not observe a significant difference in BMR change $(P=0.09)$. The progress of energy expenditure during overfeeding was examined by comparing mean TEE during the first and the second week of overfeeding. TEE increased by $0.38 \pm 0.68$ $\mathrm{MJ} /$ day from the first to the second week, but this increase was not statistically significant. Although not statistically significant, there was a tendency towards a relation between this increase in TEE and the increase in BMR, which was measured before and after overfeeding. 


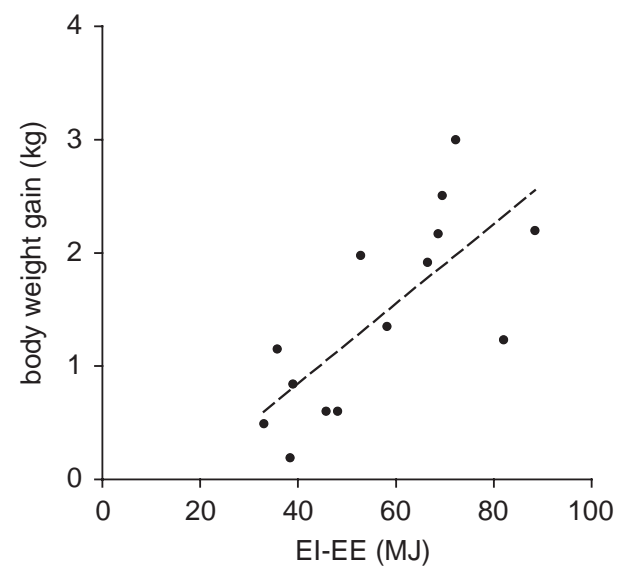

Fig. 1. Individual changes in body weight plotted against energy storage $(\mathrm{EI}-\mathrm{EE}(\mathrm{MJ}))$. EI = energy intake, $\mathrm{EE}=$ energy expenditure.

Physical activity as measured with accelerometry did not change significantly $(511 \pm 1450$ Mcounts/day). There was no difference in change in physical activity between metabolically efficient and inefficient subjects $(P=0.43)$. When we compared the subjects outside the $95 \%$ confidence interval of the mean, there was still no difference in BMR change $(P=0.12)$ or physical activity change $(P=0.50)$.

\section{Discussion}

The relevance of adaptive changes in thermogenesis in the etiology of obesity is controversial as such changes are believed to be no more than a few percent $[23,24]$. With prolonged overfeeding changes in energy expenditure are of the order of $5-15 \%$, which depends on the type and amount of overfeeding (DIT) $[25,26]$. The unexplained large inter-individual variation in efficiency of weight gain with overfeeding [1-6] shows that the matter of adaptive thermogenesis is still an issue. The aim of the present study was to investigate whether efficiency of weight gain is related to adaptive differences in BMR and physical activity by overfeeding healthy females for 14 days with a diet supplying $50 \%$ more energy than baseline requirements. If energy expenditure does not follow excess energy intake to the same extent, absolute energy storage will be greater in a subject with a baseline energy intake of for instance $12 \mathrm{MJ} /$ day $(252-168=84 \mathrm{MJ})$ compared to a subject with a baseline energy intake of $8 \mathrm{MJ} /$ day $(168-112=56 \mathrm{MJ})$. This absolute difference in excess energy intake will also influence absolute weight gain. The absolute differences allowed us to distinguish between subjects with a relatively high weight gain for the amount of energy stored (metabolically efficient) and a relatively low weight gain for the amount of energy stored (metabolically inefficient).

If any adaptive thermogenesis is present, this will show up in the BMR. Mean BMR did increase, however, when we compared those subjects that gained body weight efficiently with those that did not, we did not see any difference in BMR change. The changes in BMR were equivalent to the expected rise in DIT due to the increased amount of food eaten. The $9-10 \mathrm{~h}$ interval between the last food consumption in the evening and measurement of BMR in the morning did not eliminate influences of DIT on metabolic rate. Goldberg et al. [27] showed that after overfeeding the DIT from a large evening meal caused a higher sleeping metabolic rate compared to normal conditions. BMR measured directly at waking was still increased, despite a 13-h interval between the last meal and the measurement. This suggests that the increase in DIT due to the increased amount of food eaten persists for $24 \mathrm{~h}$ a day and is therefore observed in our BMR changes.

The most variable component of energy expenditure is AEE, which can be divided in exercise activity thermogenesis (EAT) and non-exercise activity thermogenesis (NEAT). EAT is the thermogenesis accompanied with sports participation, NEAT is defined as the thermogenesis that accompanies fidgeting, maintenance of posture, and other physical activities of daily life. The concept of NEAT seems important in energy balance regulation as in the study of Levine et al. [5] who overfed 16 non-obese subjects with $4.2 \mathrm{MJ} /$ day for 56 days, changes in NEAT directly predicted resistance to fat gain with overfeeding. In this study physical activity was registered with a triaxial accelerometer, which is sensitive to small human body accelerations and very low frequencies of accelerations and can therefore detect fidgeting [28]. Subjects maintained their normal lifestyles throughout the study period (i.e. work, education, sports participation). Mean accelerometer output did not change significantly, therefore both exercise and non-exercise activity remained constant.

When comparing TEE during the first and the second week of overfeeding there seemed to be a gradual increase in TEE, but this was not statistically significant. This increase in TEE tended towards a relation with the increase in BMR and although this relation was not statistically significant, we believe that the rise in TEE on overfeeding is largely due to an increase in BMR, and thus DIT.

However, we were not able to answer the question why some subjects can store a certain amount of energy with hardly any weight gain. We have no indications for noncompliance to the diet or measurement errors for the whole group and these subjects in particular. We can only speculate on how the excess energy was stored, by either hypertrophy or hyperplasia of the fat cells.

In short, we did not find differences in BMR and physical activity between metabolically efficient and metabolically inefficient subjects during overfeeding, indicating that the metabolic efficiency of weight gain is not related to adaptive changes in energy expenditure. 


\section{References}

[1] Norgan NG, Durnin JV. The effect of 6 weeks of overfeeding on the body weight, body composition, and energy metabolism of young men. Am J Clin Nutr 1980;33:978-88.

[2] Bouchard C.T.A, Després JP, Nadeau A, Lupien PJ, Theriault G, Dussault $\mathrm{J}$, et al. The response to long-term overfeeding in identical twins. N Engl J Med 1990;322:1477-82.

[3] Diaz EO, Prentice A, Goldberg GR, Murgatroyd PR, Coward WA. Metabolic response to experimental overfeeding in lean and overweight healthy volunteers. Am J Clin Nutr 1992;56:641-55.

[4] Roberts SB, Fuss P, Dallal GE, Atkinson A, Evans WJ, Joseph L, et al. Effects of age on energy expenditure and substrate oxidation during experimental overfeeding in healthy men. J Gerontol A Biol Sci Med Sci 1996;51:B148-57.

[5] Levine JA, Eberhardt NL, Jensen MD. Role of nonexercise activity thermogenesis in resistance to fat gain in humans. Science 1999; 283:212-4.

[6] Lammert O, Grunnet N, Faber P, Schroll Bjornsbo K, Dich J, Olesen Larsen L, et al. Effects of isoenergetic overfeeding of either carbohydrate or fat in young men. Br J Nutr 2000;84:233-45.

[7] Webb P, Annis JF. Adaptation to overeating in lean and overweight men and women. Hum Nutr Clin Nutr 1983;37:117-31.

[8] Ravussin E, Schutz Y, Acheson KJ, Dusmet M, Bourquin L, Jequier E. Short-term, mixed-diet overfeeding in man: no evidence for "luxuskonsumption". Am J Physiol 1985;249:E470-7.

[9] Forbes GB, Brown MR, Welle SL, Lipinski BA. Deliberate overfeeding in women and men: energy cost and composition of the weight gain. Br J Nutr 1986;56:1-9.

[10] Westerterp KR, Wilson SAJ, Rolland V. Diet induced thermogenesis measured over $24 \mathrm{~h}$ in a respiration chamber: effect of diet composition. Int J Obes 1999;23:287-92.

[11] Miller DS, Mumford P. Gluttony. 1. An experimental study of overeating low- or high-protein diets. Am J Clin Nutr 1967;20: $1212-22$.

[12] Horton TJ, Drougas H, Brachey A, Reed GW, Peters JC, Hill JO. Fat and carbohydrate overfeeding in humans: different effects on energy storage. Am J Clin Nutr 1995;62:19-29.

[13] Stock MJ. Gluttony and thermogenesis revisited. Int J Obes 1999; 23:1105-17.

[14] Dulloo AG, Jacquet J. Low-protein overfeeding: a tool to unmask susceptibility to obesity in humans. Int J Obes 1999;23:1118-21.
[15] Westerterp KR, Wouters L, Marken Lichtenbelt WDv. The Maastricht protocol for the measurement of body composition and energy expenditure with labeled water. Obes Res 1995;3:49-57.

[16] Siri WE. Body composition from fluid spaces and density: analysis of methods. Nutrition 1961;9:480-91; Discussion 1993;480:492.

[17] Adriaens MP, Schoffelen PF, Westerterp KR. Intra-individual variation of basal metabolic rate and the influence of daily habitual physical activity before testing. Br J Nutr 2003;90:419-23.

[18] Weir JdV. New methods for calculating metabolic rate with special reference to protein metabolism. J Physiol 1949;109:1-9.

[19] Sun M, Hill JO. A method for measuring mechanical work and work efficiency during human activities. J Biomech 1993;26:229-41.

[20] Bouten CVC, Verboeket-Van De Venne WPHG, Westerterp KR, Verduin M, Janssen JD. Daily physical activity assessment: comparison between movement registration and doubly labeled water. J Appl Physiol 1996;81:1019-26.

[21] Goris AHC, Meijer EP, Westerterp KR. Repeated measurement of habitual food intake increases under-reporting and induces selective under-reporting. Br J Nutr 2001;85:629-34.

[22] Goris AHC, Meijer EP, Kester A, Westerterp KR. Use of a triaxal accelerometer to validate reported food intakes. Am J Clin Nutr 2001;73:549-53.

[23] Dulloo AG. Thermogenesis is important in the aetiology of obesity: "the case for" (Abstract). Int J Obes Relat Metab Disord 2002;26:S6.

[24] Flatt JP. Adaptive changes in thermogenesis are not important in the aetiology of obesity (Abstract). Int J Obes Relat Metab Disord 2002; 26:S6.

[25] James WP, McNeill G, Ralph A. Metabolism and nutritional adaptation to altered intakes of energy substrates. Am J Clin Nutr 1990;51:264-9.

[26] Norgan NG. Thermogenesis above maintenance in humans. Proc Nutr Soc 1990;49:217-26.

[27] Goldberg GR, Prentice AM, Davies HL, Murgatroyd PR. Overnight and basal metabolic rates in men and women. Eur J Clin Nutr 1988; 42:137-44

[28] Bouten CV, Westerterp KR, Verduin M, Janssen JD. Assessment of energy expenditure for physical activity using a triaxial accelerometer. Med Sci Sports Exerc 1994;26:1516-23. 